\title{
Titiro Whakamuri, Hoki Whakamua:' Respectful Integration of Māori Perspectives Within Early Childhood Environmental Education
}

Jenny Ritchie, Te Whare Wānanga o Wairaka - Unitec Institute of Technology, Auckland, New Zealand

\begin{abstract}
The early years are a foundational time for the establishment of dispositions for learning. This paper draws on a recent study in Aotearoa (New Zealand) to illustrate ways educators have been implementing programs, within mainstream early childhood care and education settings, that inclusively offer Māori perspectives on caring for ourselves, others, and the environment. It argues that Indigenous perspectives provide a valid counter-narrative to the dominant Western technoindustrial emphasis that continues to damage our planet. Early childhood care and education settings are ideally situated in their capacity to provide opportunities for children, families, and communities to experience ecologically sustainable practices that are appropriately informed by local Indigenous knowledges. In the study reported here, teachers incorporated Māori cosmological narratives and local legends and applied Māori values in practical ways that demonstrated and modelled caring, sustainable ecological practices.
\end{abstract}

\section{Résumé}

Les premières années sont primordiales dans le développement des facultés d'apprentissage. Le présent article s'appuie sur une étude récemment menée à Aotearoa (Nouvelle-Zélande) pour illustrer comment les éducateurs y ont mis en œuvre des programmes, dans des contextes d'aide à la petite enfance et d'éducation préscolaire, qui ouvrent la voie à des perspectives māori sur le bien-être individuel, collectif et environnemental. L'article soutient que les perspectives autochtones opposent une solide contre-narration à la tendance techno-industrielle occidentale dominante qui persiste à ruiner notre planète. Les contextes d'aide à la petite enfance et d'éducation préscolaire sont très bien disposés à donner l'occasion aux enfants, aux familles et aux collectivités d'apprendre des pratiques écologiquement durables inspirées des savoirs autochtones. Dans cette étude, les enseignants ont intégré des récits cosmologiques et des légendes locales māori et ont appliqué les valeurs māori de façon à concevoir et mettre en évidence des pratiques respectueuses et écologiquement durables.

Keywords: Indigenous perspectives, early childhood care and education, countercolonial approaches, counter-narrative, Māori worldviews, Aotearoa, New Zealand, Indigenous knowledge 


\section{Introduction}

We are increasingly faced with evidence demonstrating the urgent seriousness of the condition of our planet Earth, whose climate, resources, bio-species, oceans, freshwater, atmosphere, and lands are precariously close to tipping over the biophysical boundaries needed to maintain stability (Stockholm Resilience Centre, 2012). This realization calls us to account as humans who are failing in our custodianship of our one and only planet. The colonization of Indigenous peoples was a process that coincided with and contributed to the spread of Western belief systems and technologies in a globalizing, competitive, ambitious, and spectacular take-over of many parts of the world, resulting in lands and resources plundered for profit and expansion. The knowledges, wisdom, languages, and ways of living in relation to places that had sustained Indigenous peoples for millennia were disregarded, as colonizers sought to increase properties, resources, wealth, and status. Indigenous peoples' traditions were devalued, their lands plundered, and their languages lost or severely jeopardized.

Traditional peoples, such as the Māori in Aotearoa (New Zealand), along with the Indigenous peoples of Australia, Canada, and elsewhere, had cosmologies and worldviews that differed greatly from those of the Western monoculture (and this is not to deny the complexities of the different colonization trajectories as they played out in different localities). Indigenous peoples lived closely and in tune with the Earth - the land, rivers and oceans, the seasons, and resources-and with great respect for its power to share or revoke life-sustaining abundance (Cardinal, 2001; Cook \& White/Xelimuxw, 2001; Kawagley, 2001; Marsden, 2003; J. E. Ritchie, 1992; D. Rose, 2005; D. B. Rose, 2000, 2002, 2003, 2004, 2011).

The narratives that are promoted and perpetuated through education and media contain powerful messages that can potentially generate respect for our planet, but unfortunately they often continue to perpetuate the Western project of domination and plunder. As Indigenous writer and scholar Thomas King (2005) reminds us, the foundational narratives of our culture(s) are hugely influential-and, as educators, we can choose to promote either the metaphors of dominance of the Western canon or those of respectful interdependence with nature, as reflected in the narratives of Indigenous peoples. In our work in early childhood care and education in Aotearoa, we have sought to share examples of practice that demonstrate ways that "mainstream" education settings are serving as sites for counter-colonial re-narrativization (see J. Ritchie \& Rau, 2010). Through relationships with Indigenous elders and knowledge-keepers, a dialogical space is being generated in which Indigenous stories are honoured. This process repositions Indigenous ways of being, knowing, and doing at the heart of the curriculum endeavour, recognizing both the wisdom and contemporary relevance of traditional knowledges. Such pedagogical counternarratives represent Indigenous understandings respectfully and inclusively 
within the discourses made available within the educational program, countering the neo-colonialism that school systems may, even unintentionally, still exert.

In the following sections I describe some of the findings from a recent project in Aotearoa that involved teachers, children, and families of 10 different early childhood care and education centres from across the country. The 20082009 project, entitled Titiro Whakamuri, Hoki Whakamua. We are the future, the present and the past: Caring for self, others and the environment in early years' teaching and learning (J. Ritchie, Duhn, Rau, \& Craw, 2010), was funded by the New Zealand Teaching and Learning Research Initiative and overseen by the New Zealand Council for Educational Research. Central to the conceptualization of the project was the willingness of participating teachers to incorporate, in a holistic manner throughout their programs, Māori perspectives pertaining to care of the environment.

\section{Backgrounding the Project}

Aotearoa has a 200-year history of colonization. The population of the Indigenous people, the Māori, was reduced by the impact of introduced illnesses, war, and demoralization from estimates of 150,000-200,000 in the early 1800s (Jackson, 1931) to 44,177 by 1891,51 years after the signing of the Treaty of Waitangi, by Māori and the British Crown, which explicitly stated intentions to protect Māori, their lands, and resources (Orange, 2004). Captain James Cook, in leading the British expedition to the South Seas, had inadvertently "carried with him the ideas that would eventually subvert those of indigenous cultures and colonise them... and, even more disastrously, the pathogens that would eventually kill hundreds of thousands of people who had no immunity to them" (M. King, 2003, p. 107).

Despite the onslaught of colonialist legislation and policies, Māori maintained an unrelenting faith in their beliefs, language, values, and traditions. They continued over many years to push for recognition and redress for the transgressions of the protections that had been promised in the 1840 Treaty (Walker, 2004). Since 1975, various government initiatives have gone some way in acknowledging both the Tiriti o Waitangi (Treaty of Waitangi) and its implications regarding protections. In 1996, the efforts of early childhood care and education academics Helen May and Margaret Carr, working in partnership with Māori academics Tilly and Tamati Reedy, culminated in the first bicultural education curriculum for the country: Te Whāriki. He whäriki mātauranga mō nga mokopuna o Aotearoa: Early childhood curriculum (Ministry of Education, 1996). Yet, concern has been expressed about the capacity of the profession to meet the sophisticated demands of this non-prescriptive curriculum model, which requires that early childhood care and education practitioners work with families and children in each particular setting to "weave" their own version of the curriculum (Cullen, 2003; May, 2001; Nuttall, 2003; J. Ritchie, 2003a). 
The teaching workforce in Aotearoa reflects the demographics of the wider society. The most recent population census of 2006 found that only $1.6 \%$ of Pākeh $\bar{a}$ (New Zealanders who have European ancestry) responded that they could speak Māori, whilst $24 \%$ of Māori reported that they were speakers of their language (Statistics New Zealand/Tatauranga Aotearoa, 2010). In 2011, 9.1\% of the early childhood care and education teacher workforce were Māori (Ministry of Education, 2012). Early childhood care and education teachers, as with the wider society, are predominantly monolingual English speakers, although most make an effort to include some Māori language in deference to the requirements of the curriculum (Harkess, 2004).

Despite gaining "official" status in 1987 as a result of Māori activism, the Māori language is not required to be taught to any level of competence within the school system. This widespread Euro/Anglo-centric monoculturalism and monolingualism creates challenges regarding the implementation of a national early curriculum requiring that "all children should be given the opportunity to develop knowledge and an understanding of the cultural heritages of both partners to Te Tiriti o Waitangi" (Ministry of Education, 1996, p. 9).

In relation to matters pertaining to environmental education, the curriculum is expected to demonstrate "recognition of Māori ways of knowing and making sense of the world and of respecting and appreciating the natural environment" (1996, p. 82), and that "liaison with local tangata whenua (Māori people of that particular locality)" (p. 54), and respect for Papatūanuku (the Earth Mother) should be promoted. Further expectations include that children should have opportunities to develop "a relationship with the natural environment and a knowledge of their own place in the environment; respect and a developing sense of responsibility for the well-being of both the living and the non-living environment; [and] working theories about the living world and knowledge of how to care for it" (Ministry of Education, 1996, p. 90).

A sense of connectedness to the environment can be fostered by practices outlined in the Ministry of Education (1996) document, such as ensuring that "infants have opportunities to experience patterns and sounds in the natural environment, such as leaves in sunlight or the sound of rain" (p. 81). The document also outlines that through gaining the social and cooperative skills of "working and playing together, children develop a sense of responsibility for the well-being of others and the environment" (p. 98). The parallel Māori section in the early childhood curriculum, Te Whăriki (Ministry of Education, 1996), intended predominantly for Māori immersion settings, speaks of our inter-relatedness as descendants of the Earth Mother and Sky Father, and the expectation that kaiako (teachers) research stories of the local area, the mauri (life force), te wairua kei roto $i$ te whenua (the spirit in and of the land), te rāhui (conservation restrictions), and taniwhā (local supernatural guardians). Children are to be taught to care for Papatūanuku (Earth Mother), ngā rākau (trees), ngā putiputi (flowers), ngā huawhenua (vegetables), ngā ngārara 
(insects), and ngā manu (birds) (translations by author), all of whom are descendants of the Earth Mother and Father, and therefore, all our relations. The curriculum further states that children should learn knowledges of gardening, fishing, and gathering seafood.

The complexity and range of understandings and skills required by teachers in order to deliver early childhood care and education programs reflective of both Māori and Pākehā constructions is clearly a challenge, one which was taken up in the project outlined below.

\section{Research Questions and Methodology}

The methodological paradigm of this study was qualitative and informed by narrative (Clandinin, 2007; Clandinin et al., 2006; Schulz, Schroeder, \& Brody, 1997) and kaupapa Māori (Māori philosophy) research perspectives (Bishop, 2005; Lee, 2005; G. H. Smith, 1997; L. T. Smith, 1999). The project was focused around four key areas of interest:

1. What philosophies and policies guide teachers and whänau (families) in their efforts to integrate issues of ecological sustainability into their current practices?

2. How are Māori ecological principles informing and enhancing a kaupapa (philosophy) of ecological sustainability, as articulated by teachers, tamariki (children), and whänau?

3. In what ways do teachers and whanau articulate and/or work with pedagogies that emphasize the interrelationships between an ethic of care for self, others, and the environment in local contexts?

4. How do/can early childhood education centres work with their local community in the process of producing ecologically sustainable practices?

The project received institutional ethical approval and ongoing vigilance was maintained in regards to both Indigenous and Western ethical protocols. Teachers from 10 different early childhood care and education centres nationally worked alongside four co-directors and an additional research facilitator located in the South Island city of Dunedin. An initial day-long hui (meeting) was held at a University marae (Māori meeting house) to establish some common ground of shared understandings regarding research questions, expectations for ethical considerations, kaupapa Māori understandings pertinent to the project, and the planning of data-gathering strategies (Bishop, 2005; L. T. Smith, 1999).

During the following year, co-directors and the research facilitator worked closely with the teachers, engaging in co-theorizing discussions that were also recorded and formed part of the data, along with policy statements, pedagogical documentation, recorded interviews and video of parents and children, photographs, and examples of children's stories and art. Ongoing attention to 
ethical matters was managed through the closeness of the relationships, both between research directors/facilitator and teachers, as well as between teachers and the children and their families, which allowed for honest exchanges and responsiveness. A kuia and kaumātua (female and male Māori elder, respectively) supported and guided the entire process. A final hui was held towards the end of the two-year period, at which all the teachers presented highlights of their research journey. These presentations, and the intervening discussions, were also recorded and formed a final segment of data.

In the remainder of this paper I present examples from these "mainstream" early childhood care and education settings where the teachers worked hard to bring Māori perspectives to the focus of their teaching around "caring for ourselves, others and the environment," and in alignment with the expectations of the New Zealand national early childhood curriculum, Te Whāriki.

\section{Demonstrating Manaakitanga and Kaitiakitanga Within Early Childhood Care and Education}

The teachers who joined the project had a range of background experiences. Five of the 10 early childhood care and education centres had been involved in previous research projects (J. Ritchie \& Rau, 2006, 2008) that had had a strong focus on the implementation of the kaupapa Māori expectations of the early childhood curriculum, Te Whäriki. Yet, despite their pre-existing commitment to bicultural teaching, even some of the teachers from these centres expressed initial anxiety about how to address the second research question, which required a focus on Māori ecological principles. Other teachers had a strong interest in issues of education for sustainability, yet also lacked an understanding of how to bring Māori perspectives into their teaching of education for sustainability. Two of the centres involved were "Enviroschools," kindergartens committed to implementing Māori ecological principles (Enviroschools/Kura Taiao, 2012). We spent some time at the initial hui outlining key Māori constructs that the teachers might consider applying in their teaching, such as manaakitanga (caring) and kaitiakitanga (guardianship). We provided the teachers with some initial printed material pertaining to kaupapa Māori understandings. Further information was made available via our research website, and we continued discussing applications of these ideas on our regular visits during the project.

Reflecting their nature as a collectivist society, Māori place great importance on the responsibilities of individuals to uphold the mana (prestige) of the wider collective. Manaakitanga is part of this process and requires demonstration of offering and receiving generosity, care, respect, kindness, and hospitality, which results in the upholding of the mana of both giver and recipient (Benton, Frame, $\&$ Meredith, 2007). Enactment of manaakitanga involves an ongoing cycle of reciprocity: 
Reciprocity is also involved in the concept or value of manaakitanga, which involves nurturing relationships, looking after people, and being very careful of how people are treated, and expecting the same care in return. This includes relatives but also extends beyond them to all manuhiri (visitors). It is one of the key regulators in the interaction of Māori communities, and of Māori and Pākehā (from a Māori point of view). (Waitangi Tribunal, 2004, p. 11)

Many examples of manaakitanga were demonstrated during our study. The teachers of Richard Hudson Kindergarten, located in the South Island city of Dunedin, described how, with the support of Huata Holmes, a local Southern Māori elder, they had introduced children to the Māori cosmological story in which the children of Papatüanuku (the Earth Mother) and Ranginui (the Sky Father) separated their parents to generate space and light for growth. This had great resonance with the children, as seen in the following example:

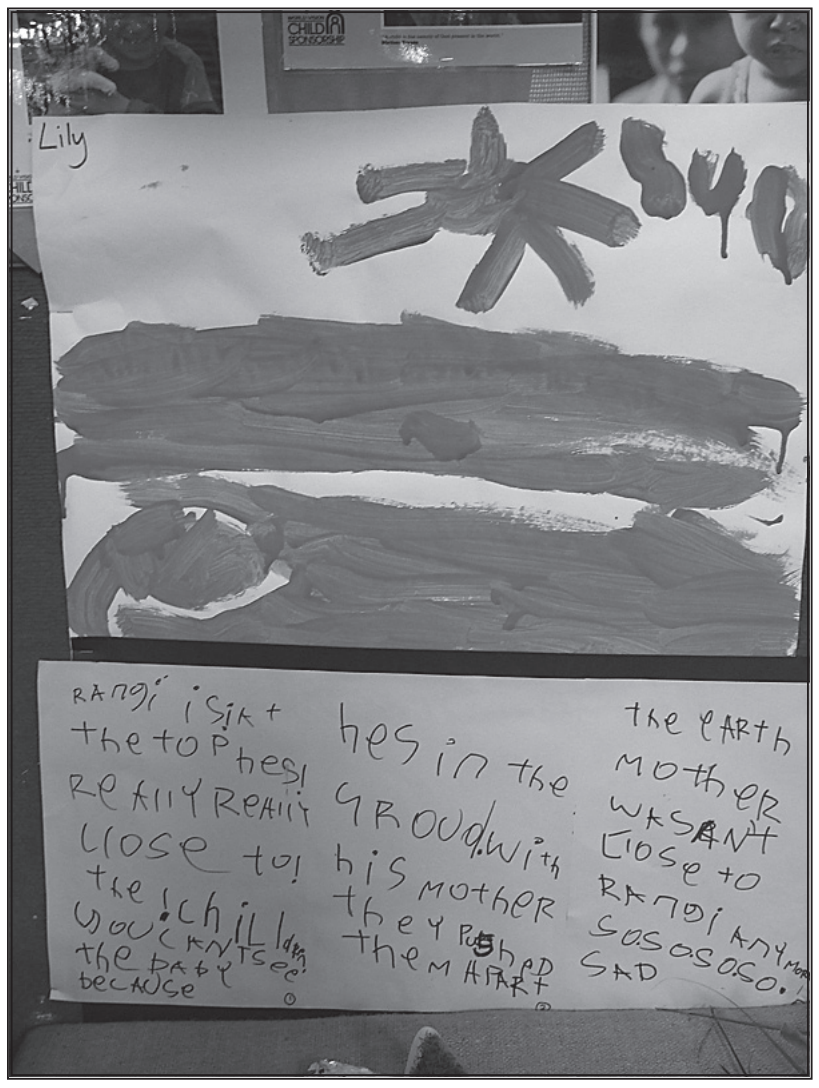

Lily's Story: Rangi (Ranginui) is at the top. He is really, really close to the children. You can't see the baby because he's in the ground with his mother. They pushed them apart. The earth mother wasn't close to Rangi anymore. So So So So. Sad. 
One teacher explained:

Lily shows her clear understanding of this story. Her empathy with their feelings of sadness is beautiful. Lily has the ability to write her story down as well as portray it through her art. These forms of communication allow her a depth of expression and creation as she makes sense of her world. [Richard Hudson Kindergarten teacher]

The teachers from this kindergarten introduced into our study the phrase "community empathy" as a description of their application of manaakitanga through many practical strategies. These strategies included: regular visits to a neighbourhood elder-care home, a "Wacky Hair Day" fundraiser for the Otago Children's Autism Support Group, collecting food for the local Society for the Prevention of Cruelty for Animals, and the establishment of a "free shelf" at the kindergarten whereby families could drop off unwanted clothing, shoes, books, and toys for others. Many of the other centres in the study had similar strategies of reciprocity, one of which was an "Out of our own back yards" bowl, where excess fruit and vegetables grown both at home and at the Raglan Childcare and Education Centre were deposited for redistribution. Parental and community involvement resulted in the extension of many of these activities into the wider communities, as the teachers, children, and families from many centres participated in beach clean-ups, tree planting events in conjunction with local marae (Māori communities), and the collection of clothing, books, and toys for redistribution in Kenya via the liaison with a visiting Kenyan teacher education student by the Raglan centre.

Kaitiakitanga (guardianship) reflects the Māori sense of interconnectedness with the living and non-living world, on which we depend for survival. In contemporary contexts, it reflects an "ethic of guardianship or trusteeship, especially over natural resources" (Benton et al., 2007, p. 90). It is also associated with a responsibility for the active engagement of manaakitanga: caring for, rather than merely caretaking of, the natural world (Waitangi Tribunal, 2004). The teachers from Koromiko Kindergarten in the small North Island rural community of Hawera described how they began their work for the project, focusing on Māori constructs such as kaitiakitanga: 


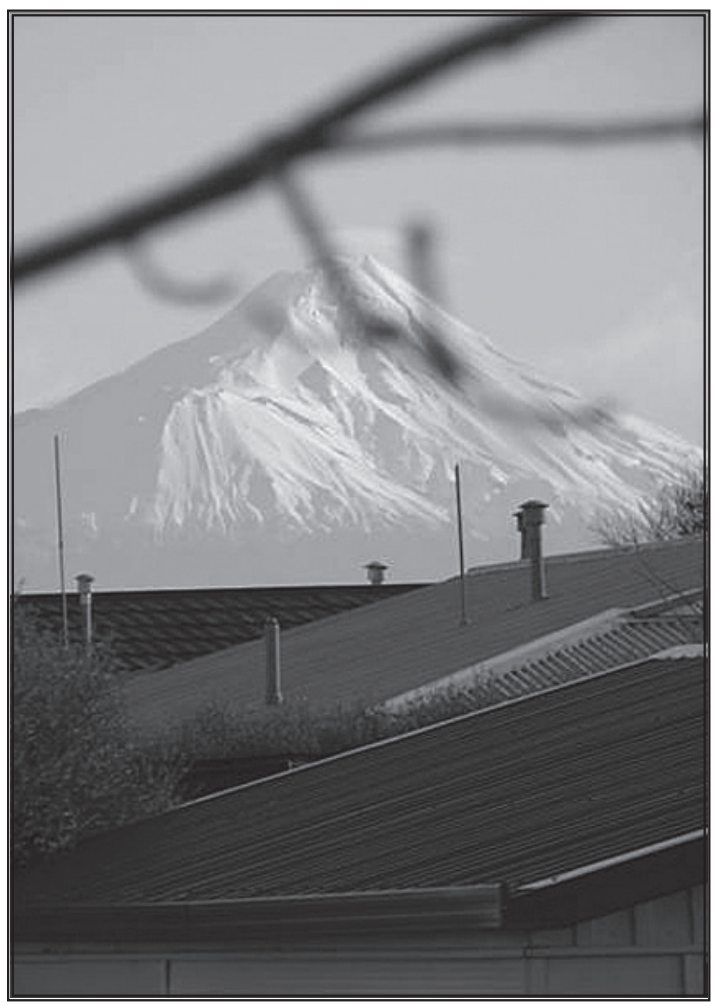

The beginning of the research project had an impact in a number of ways. We began to think about how Māori values, practices, and culture tie in with the principles we wanted to promote. The concept of kaitiakitanga (being guardians over the well-being of the environment and the creatures in it-including us) gives a holistic view of what we are doing ... We can see our mountain, Mt. Taranaki/ Egmont, from the playground. It is a symbol of our province and very important to the people of Taranaki and, particularly, the local iwi [tribe]. When looking at environmental issues, it is an everpresent reminder of what we are wanting to preserve.

[Koromiko Kindergarten teacher]

Mt Taranaki, as seen from Koromiko Kindergarten

From their research they decided to introduce to their centre the whakatauki (proverb) Manaaki whenua. Manaaki tangata. Haere whakamua (Care for the land. Care for the people. Go forward). They described how they applied this whakatauki:

This is the whakatauaki that informs and guides our research. With the principles of Education for Sustainability, we want to practise ourselves, and promote the idea for our tamariki and whānau, about being kaitiaki (guardians/caretakers) of our land and living things. It applies directly to caring for the kindergarten grounds and pets but also to the wider environment. [Koromiko Kindergarten teacher]

Gwyneth Barker, a teacher from Koromiko Kindergarten, later wrote an article describing her centre's involvement in the project. She wrote:

The data we gathered reflected our own interests in caring for the environment. We began to see and talk about what we were doing and teaching the children in terms 
of the principle of 'kaitiakitanga'; that we were being guardians/caretakers (kaitiaki) of the environment and all living things in that environment. Books portraying Māori legends, particularly about Tane and Tangaroa being guardians of the forests and the sea, and all living creatures in these areas, proved effective in helping the children to grasp some of the concepts. (Barker, 2010, p. 15)

Marina Bachmann, an early childhood care and education centre owner and director of Collectively Kids Childcare and Education Centre in the large urban setting of Auckland, had been the instigator of our project's focus on sustainability due to her heartfelt concern for these matters. During the study she read further about Māori ecological beliefs and reflected on their application within her centre:

In terms of sustainability I think (from reading I have done) that our approach to care of the environment is fairly compatible with manaakitanga and kaitiakitanga. I personally believe that nature is not something we can own and control. We are a part of (not above) nature and have a responsibility to use resources in a way that doesn't damage the system as a whole. If we don't take this responsibility seriously it is likely to cost us dearly.

A particular strategy of kaitiakitanga was employed by Adelle Ellwood of Richard Hudson Kindergarten, who researched and then applied the Māori conservation practice of rāhui (prohibition):

Through reading widely for this research, I have deepened my understandings about conservation from a Māori perspective. I feel that my understandings are becoming layered now as I add more knowledge to what I already know. It was while trawling through the Te Ara/New Zealand Encyclopedia site that I saw the heading "Conservation Through Rāhui." It interested me and "planted a seed of thought" in my mind. It talked about limits being placed on resources when they were scarce to ensure their continuation in the long term. It explained that the limits were localized, and entirely respected and adhered to. When I heard the other teachers talking about the flowers from the front steps being picked, the idea in my head began to germinate. We had a parallel situation here at kindergarten - a localized shortage on a precious resource. I could teach the children about conservation through rāhui. This Māori conservation concept would be hard for children to understand without a practical application, or a real context. This was the perfect opportunity to teach it meaningfully, to plant a seed of understanding in their minds, as they develop their bicultural understandings of the necessity for such concepts. The flowers on the front steps had a rähui placed on them to ensure they lasted, and flowers for the enjoyment and creativity of the children were sourced elsewhere. And it worked!

At Papamoa Kindergarten, the teachers utilized the Māori construct of taonga tuku iho (precious gifts from the ancestors) in relation to water, which in te ao Māori (the Māori worldview) is conceptualized as the tears of Ranginui (the Sky Father): 
We believe as a team that water is a great teacher. Children learn that water, as a Māori concept, is taonga tuku iho, a precious resource with our water recycling system. Water is collected off the roof in a barrel then children pump the water across the grass area into the sandpit. They have a gauge that shows them how much water is in the barrel. Children then can decide how the water will be used. We talk with them about using vessels to catch the water and we have provided tarpaulins for children to use to hold the water. Children will teach and learn from each other how the system works, telling each other when to turn taps off and pump more water.

[Papamoa Kindergarten teacher]

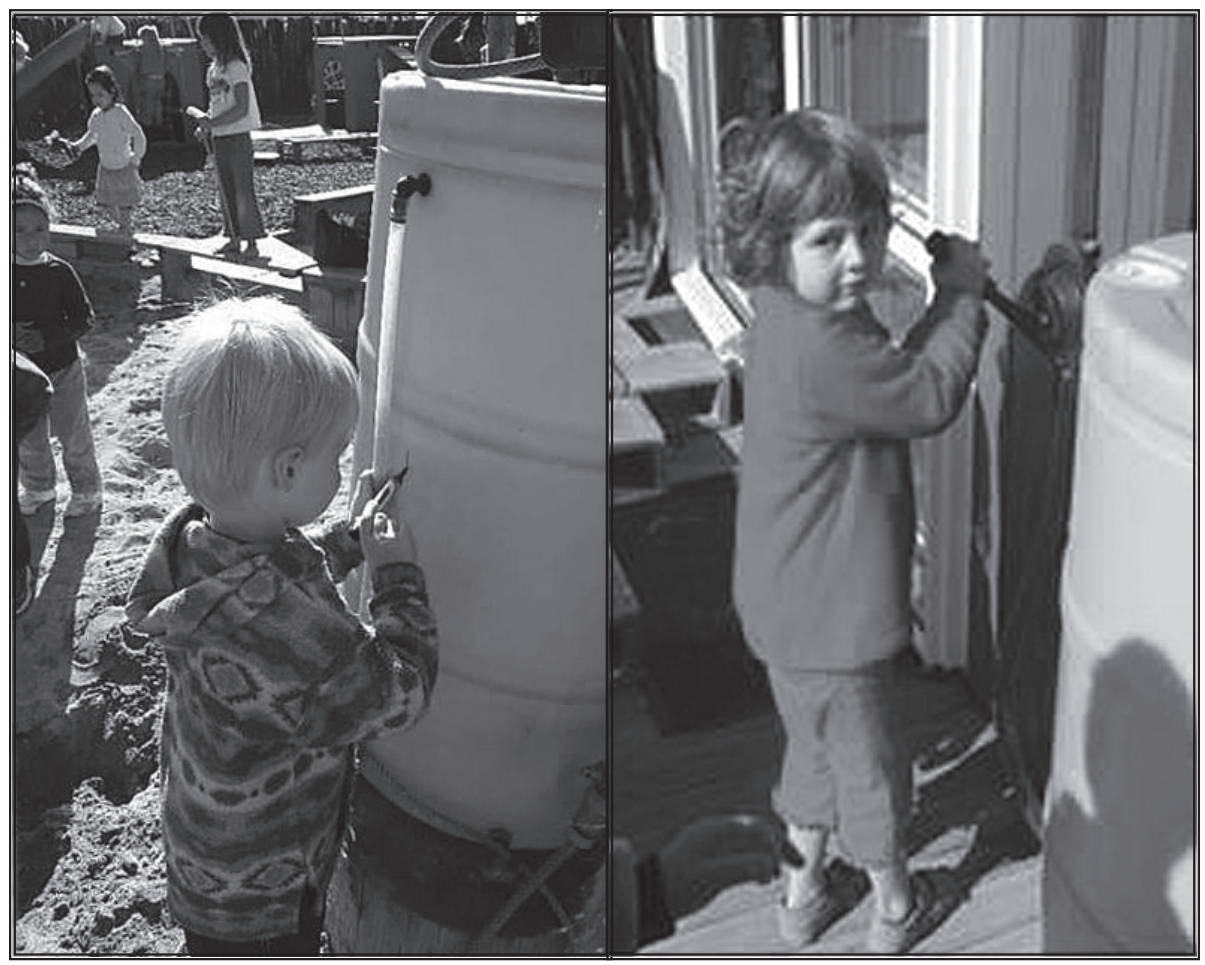

Water conservation at Papamoa Kindergarten

The teachers of the Raglan Childcare and Education Centre provided a narrative that expressed the notions of kaitiakitanga and manaakitanga in relation to a visiting monarch butterfly: 
We have been learning lots about the life cycle of a butterfly lately. "T" gently holds a butterfly on his hand, telling us, "Don't touch its wings or it will die." Lots of children gather round to see and tell us about monarch butterflies they have seen.

Learning outcomes: T shows care and respect for living things. T shares his knowledge of living things with his peers and adults. [Raglan Childcare and Education Centre teacher]

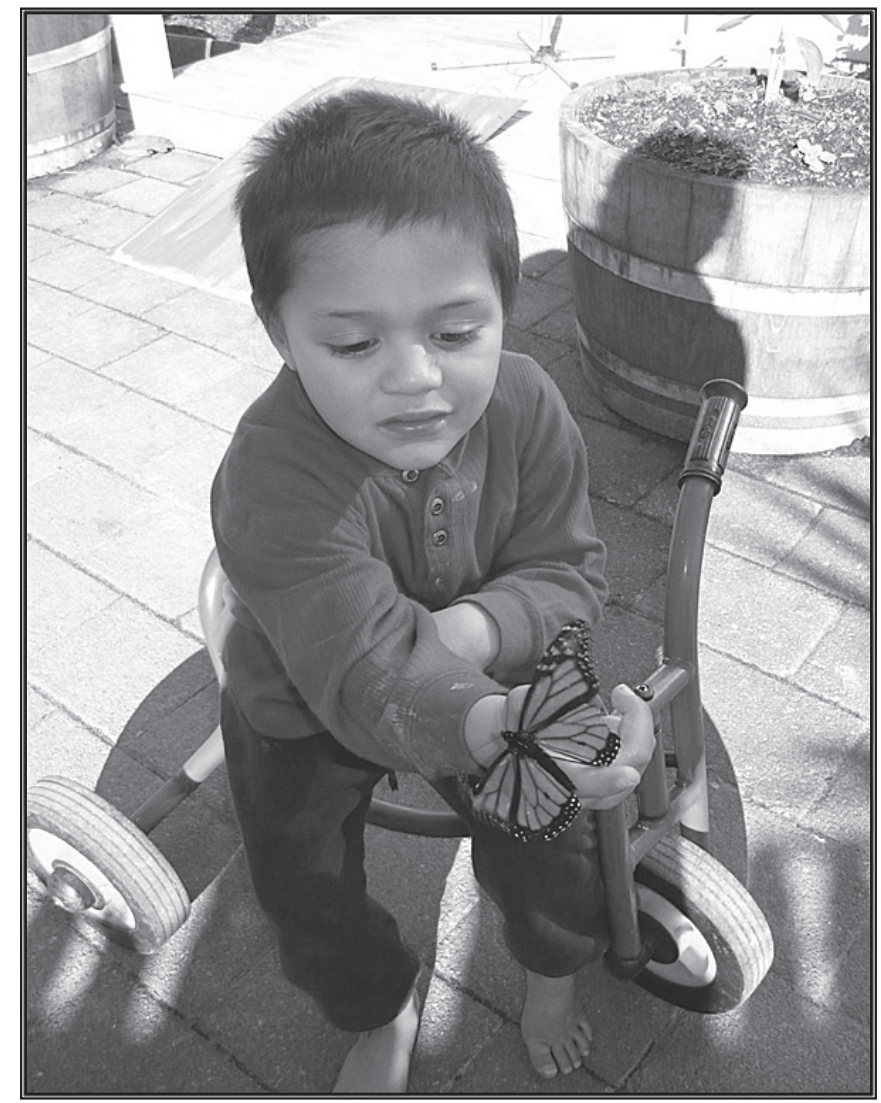

"T" with the Monarch Butterfly

Relationships with local Māori are an important aspect in the implementation of pedagogies respectful of Māori epistemologies. Teachers who are not Māori often feel uncomfortable being positioned as teacher/experts charged with implementing the national bicultural early childhood curriculum, aware of the limitations of their Māori knowledge (J. Ritchie, 2003b). Teachers in our study 
valued the relationships they formed with Māori in their communities, and these relationships proved to be an inestimable source of learning for them. As trust developed, these relationships gave entry into new arenas of experience and knowledge. Here is an overview provided by teachers of Papamoa Kindergarten, of an interview with a Māori parent:

\begin{abstract}
We talked about different aspects of our program and "E" felt that to enhance the Maori side of our environmental program that we could use the [Māori traditional] fishing and planting charts a bit more and get back into weaving, maybe using a community member. We talked about the children saying karakia (grace) before food. She felt that maybe with so many families moving through the kindergarten that this may not be understood and that constant reminding would be good. The pepeha [proverb-in this case being used as a format in which children identified their families and landmarks] she felt was a good idea as it gave children a sense of belonging. She said it was important for the community and that children can share their stories about their family. She had an idea about using a talking stick like they do at the marae for children to tell their stories. It would be good as a prompt [in] recall of their knowledge. She saw it that the children being seen out in the community contributes to the community valuing children. E felt that the children understood the Matariki [Māori New Year] festival and that they loved the concept and story about the stars. We talked about children caring for their environment and she said that is visible in our native [plants] garden. Children will spend time in there, show respect and care for the plants. She believes that because children are involved in planting and caring that they do have a different perspective and ownership of the kindergarten environment. They see garden and recycling systems working everyday and see the time and work that goes in to it. By being engaged they can gain an understanding of the processes, something you could never explain to them. She says it is the experience: "Experience is the way to learn about things at this age." [Papamoa Kindergarten teacher]
\end{abstract}

This narrative demonstrates the potential of "slow and experientially driven pedagogies" such as gardening (Cutter-Mackenzie, 2009, p. 133), whereby spaces of belonging are generated for Indigenous parents and their children. This facilitates the intergenerational transmission of cultural knowledges and thus widens the discourses made available to all attending children, offering an alternative to the hegemonic Western messages of the corporate market/ consumer monoculture (Bowers, 2009).

\title{
Conclusion
}

In this article, it has been my intention to offer an optimistic perspective, in a portrayal of the efforts of some dedicated educators to recognize and honour their commitment to Indigenous peoples and Māori ways of knowing, being, and doing (Martin, 2007) within early childhood teaching practice in Aotearoa. This work is happening in a country with a long history of colonization, cultural oppression, and language loss. The teachers included in their programs 
explorations of Māori cosmological narratives and legends of traditional environmental spiritual guardians, along with applications of Māori values of manaakitanga and kaitiakitanga in practical ways. The impact of this respectful integration of Māori values emanated into the wider communities and beyond. Significant factors in enabling this counter-colonial re-narrativization included the mandate of a national early childhood curriculum that requires a bicultural or bi-epistemic approach, and support within the teachers' teaching teams and from management. Most importantly, it included a great deal of commitment and effort on the part of the teachers to extend themselves as intercultural teacher-allies who, through their proactive engagement in learning more about te ao Māori (the Māori worldview), and their openness, receptivity, and warmth, were able to foster relationships with Māori and other parents, families, and communities, which in turn generated pedagogical transformation in service of an ethic of care for our environment.

\section{Glossary of Māori terms}

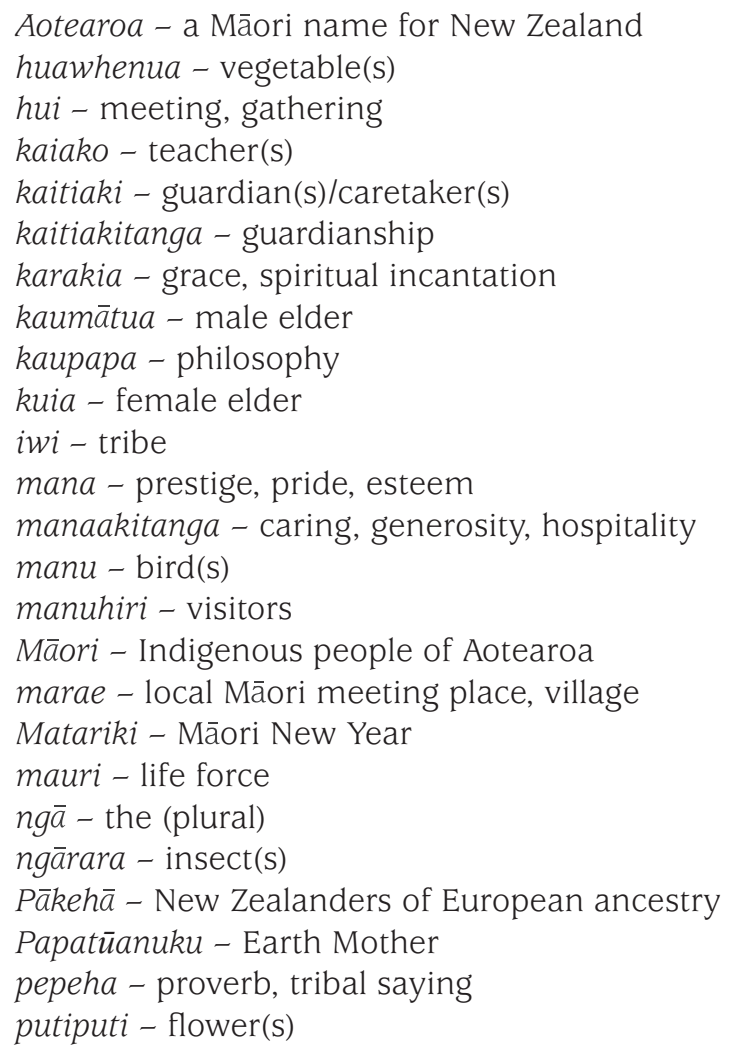


rāhui - conservation restriction, prohibition to protect resources

rākau - tree(s)

Ranginui - the Sky Father

tamariki - children

Tane - spiritual guardian of the forests

Tangaroa - spiritual guardian of the sea

tangata whenua - "people of the land": Māori people of that particular locality

taniwh $\bar{a}$ - local supernatural guardian(s)

taonga tuku iho - precious gifts from the ancestors

te - the (singular)

te ao Māori - the Māori worldview

te wairua kei roto i te whenua - the spirit in/of the land

Te Whäriki - literally "The Woven Mat"

whakatauki - proverb

whānau - family/ies

\section{Notes}

1 Titiro Whakamuri, Hoki Whakamua is a Māori proverb which relates to te ao Māori, the Māori worldview, that the present is very much informed by the past. It is also the first part of the title of our recent research project (J. Ritchie et al., 2010), funded by the New Zealand Teaching and Learning Research Initiative, to whom we are most grateful.

2 Aotearoa is a Māori name for New Zealand. On the first occurrence of a Māori word, a translation is provided in brackets; in addition, a glossary of Māori words is provided (above).

\section{Notes on Contributor}

Jenny Ritchie has a background as a childcare educator and kindergarten teacher, followed by 22 years' experience in early childhood teacher education. Her teaching, research, and writing has focused on supporting early childhood educators and teacher educators to enhance their praxis in terms of enacting an awareness of cultural, environmental, and social justice issues.

Contact: jritchie@unitec.ac.nz

\section{References}

Barker, G. (2010). Building sustainable communities. 'Manaaki whenua. Manaaki tangata. Haera whakamua'. Early Education, 47, 15-18.

Benton, R., Frame, A., \& Meredith, P. (Eds.). (2007). Te mātāpunenga: A compendium of references to the concepts and institutions of Māori customary law. Hamilton, NZ: Te 
Mātāhauariki Research Institute at the University of Waikato.

Bishop, R. (2005). Freeing ourselves from neocolonial domination in research: A Kaupapa Māori approach to creating knowledge. In N. K. Denzin \& Y. S. Lincoln (Eds.), The Sage handbook of qualitative research ( $3^{\text {rd }}$ ed.) (pp. 109-164). Thousand Oaks, CA: Sage.

Bowers, C. (2009). Educating for a revitalization of the cultural commons. Canadian Journal of Environmental Education, 14, 196-200.

Cardinal, L. (2001). What is an Indigenous perspective? Canadian Journal of Native Education, 25(2), 180-182.

Clandinin, D. J. (Ed.). (2007). Handbook of narrative inquiry: Mapping a methodology. Thousand Oaks, CA: Sage.

Clandinin, D. J., Huber, J., Huber, M., Murphy, M. S., Orr, A. M., Pearce, M., \& Steeves, P. (2006). Composing diverse identities: Narrative inquiries into the interwoven lives of children and teachers. London and New York: Routledge.

Cook, P., \& White/Xelimuxw, W. (2001). Thunderbirds, thunder-beings, thunder-voices: The application of traditional knowledge and children's rights in support of Aboriginal children's education. The American Review of Canadian Studies, Spring/Summer, 331-347.

Cullen, J. (2003). The challenge of Te Whariki: Catalyst for change? In J. Nuttall (Ed.), Weaving Te Whäriki. Aotearoa New Zealand's early childhood curriculum document in theory and practice (pp. 269-296). Wellington, NZ: New Zealand Council for Educational Research.

Cutter-Mackenzie, A. (2009). Multicultural school gardens: Creating engaging garden spaces in learning about language, culture, and environment. Canadian Journal of Environmental Education, 14, 122-135.

Enviroschools/Kura Taiao. (2012). The enviroschools foundation. Retrieved from http://www. enviroschools.org.nzl

Harkess, C. (2004). Ethnicity in the early childhood education teacher-led workforce. Wellington, NZ: Demographic and Statistical Analysis Unit, Ministry of Education. Retrieved from http://edcounts.squiz.net.nzl_data/assets/pdf_file/0010/9766/ethnicity-ece-teacher-ledworkforce.pdf.

Jackson, P. M. (1931). Maori and education: Or the education of Natives in New Zealand and its dependencies. Wellington, NZ: Fergusson and OsbornLtd.

Kawagley, A. O. (2001). Spirit, knowledge, and vision from our First Nations' sages. Canadian Journal of Native Education, 25(2), 199-206.

King, M. (2003). The penguin history of New Zealand. Auckland, NZ: Penguin.

King, T. (2005). The truth about stories: A Native narrative. Minneapolis, MN: University of Minnesota Press.

Lee, J. (2005). Māori cultural regeneration: Pūrākau as pedagogy. Paper presented at the Centre for Research in Lifelong Learning International Conference, Stirling, SCT.

Marsden, M. (2003). The woven universe: Selected writings of Rev. Māori Marsden. T. A.C. Royal (Ed.). Wellington, NZ: The Estate of Māori Marsden.

Martin, K. (2007). Making tracks and reconceptualising Aboriginal early childhood education: An Aboriginal Australian perspective. Childrenz Issues, 11(1), 15-20.

May, H. (2001). Politics in the playground. The world of early childhood in postwar New Zealand. Wellington, NZ: Bridget Williams Books and New Zealand Council for Educational Research. 
Ministry of Education. (1996). Te Whāriki. He whāriki mātauranga mō ngā mokopuna o Aotearoa: Early childhood curriculum. Wellington, NZ: Learning Media.

Ministry of Education. (2012). Education counts. Maori in ECE. Wellington, NZ: Ministry of Education. Retrieved from http://www.educationcounts.govt.nz/statistics/ece2/mori-in-ece.

Nuttall, J. (2003). Introduction. In J. Nuttall (Ed.), Weaving Te Whāriki: Aotearoa New Zealand's early childhood curriculum document in theory and practice (pp. 5-15). Wellington, NZ: New Zealand Council for Educational Research.

Orange, C. (2004). An illustrated history of the Treaty of Waitangi. Wellington, NZ: Bridget Williams Books.

Ritchie, J. (2003a). Te Whāriki as a potential lever for bicultural development. In J. Nuttall (Ed.), Weaving Te Whäriki: Aotearoa New Zealand's early childhood curriculum document in theory and practice (pp. 79-109). Wellington, NZ: New Zealand Council for Educational Research.

Ritchie, J. (2003b). Whakawhanaungatanga: Dilemmas for mainstream New Zealand early childhood education of a commitment to bicultural pedagogy. Paper presented at the $11^{\text {th }}$ Reconceptualizing Early Childhood Conference, January 5-12, Tempe, AZ. Retrieved from http://profile.educ.indiana.edu/Portals/15/Presentations/ResearchPresentationRecon.pdf

Ritchie, J., Duhn, I., Rau, C., \& Craw, J. (2010). Titiro Whakamuri, Hoki Whakamua. We are the future, the present and the past: caring for self, others and the environment in early years' teaching and learning. Wellington, NZ: Teaching and Learning Research Initiative/New Zealand Centre for Educational Research. Retrieved from http://www.tlri.org.nz/sites/ default/files/projects/9260-finalreport.pdf

Ritchie, J., \& Rau, C. (2006). Whakawhanaungatanga. Partnerships in bicultural development in early childhood education. Final report to the Teaching \& Learning Research Initiative Project. Wellington, NZ: Teaching Learning Research Institute/New Zealand Centre for Educational Research. Retrieved from http://www.tlri.org.nz/pdfs/9207_finalreport.pdf

Ritchie, J., \& Rau, C. (2008). Te Puawaitanga - partnerships with tamariki and whänau in bicultural early childhood care and education. Final report to the Teaching Learning Research Initiative. Wellington, NZ: Teaching Learning Research Institute/New Zealand Centre for Educational Research. Retrieved from http://www.tlri.org.nz/pdfs/9238_finalreport.pdf

Ritchie, J., \& Rau, C. (2010). Kia mau ki te wairuatanga: Counter-colonial narratives of early childhood education in Aotearoa. In G. S. Cannella \& L. D. Soto (Eds.), Childhoods: $A$ handbook (pp. 355-373). New York: Peter Lang.

Ritchie, J. E. (1992). Becoming bicultural. Wellington, NZ: Huia Publications.

Rose, D. (2005). An Indigenous philosophical ecology: Situating the human. The Austratian Journal of Anthropology, 16(3), 294-305.

Rose, D. B. (2000). Dingo makes us human: Life and land in an Australian Aboriginal culture. Cambridge, UK: Cambridge University Press.

Rose, D. B. (2002). Dialogue with place: Toward an ecological body. Journal of Narrative Theory, 32(3), 311-325.

Rose, D. B. (2003). Decolonizing the discourse of environmental knowledge in settler societies. In G. Hawkins \& S. Muecke (Eds.), Culture and waste: The creation and destruction of value (pp. 53-72). Lanham, MD: Rowman \& Littlefield.

Rose, D. B. (2004). Reports from a wild country: Ethics for decolonisation. Sydney, NZ: University of New South Wales. 
Rose, D. B. (2011). Wild dog dreaming: Love and extinction. Charlottesville \& London: University of Virginia Press.

Schulz, R., Schroeder, D., \& Brody, C. M. (1997). Collaborative narrative inquiry: Fidelity and the ethics of caring in teacher research. Qualitative Studies in Education, 10(4), 473-485.

Smith, G. H. (1997). The development of Kaupapa Maori: Theory and praxis (Unpublished Doctor of Philosophy in Education Thesis). University of Auckland, Auckland.

Smith, L. T. (1999). Decolonizing methodologies: Research and Indigenous peoples. London and Dunedin: Zed Books and University of Otago Press.

Statistics New Zealand/Tatauranga Aotearoa. (2010). The social report. Te pürongo oranga tangata. Cultural identity. Wellington, NZ: Statistics New Zealand. Retrieved from http:// www.socialreport.msd.govt.nz/documents/cultural-identity-social-report-2010.pdf

Stockholm Resilience Centre. (2012). Tipping towards the unknown. Stockholm: Stockholm University. Retrieved from http://www.stockholmresilience.org/planetary-boundaries

Waitangi Tribunal. (2004). Report on the Crown's foreshore and seabed policy. Wai 1071. Wellington, NZ: Legislation Direct. Retrieved from http://www.waitangi-tribunal.govt.nz/reports/ viewchapter.asp? reportID = 838C5579-36C3-4CE2-A444-E6CFB1 D4FA01 \&chapter $=3$.

Walker, R. (2004). Ka Whawhai Tonu Matou. Struggle without end (revised ed.). Auckland, NZ: Penguin. 